\author{
Jakub Z. Lichański \\ ORCID: 0000-0002-1943-5069 \\ Uniwersytet Warszawski
}

https://doi.org/10.19195/1642-5782.19(29).2

\title{
Czy protreptyk wart jest przywrócenia w edukacji szkolnej?
}

Interesującym zjawiskiem we współczesnej dydaktyce są próby przywracania w niej pewnych metod znanych i stosowanych od czasów antycznych ${ }^{1}$. Co zaskakujące, próby te obejmują nie tylko szkolnictwo wyższe czy średnie, ale także na przykład szkoły biznesu! Wiązać to można z oczywistą i dość powszechną metodą, która kładzie duży nacisk na rozwój między innymi krytycznego myślenia ${ }^{2}$, a także samodzielne rozwiązywanie problemów przez uczniów bądź studentów w toku na przykład dyskusji. Kwestie, które przedstawię, wiążą się z propozycją odnowienia jednej z najbardziej znanych w dawnej dydaktyce metod, a mianowicie - protreptyku.

Niniejsze rozważania wypada zacząć od przypomnienia, czym jest protreptyk $^{3}$. Mówiąc najkrócej, to klasyczna metoda rozwiązywania problemów, szczególnie etycznych bądź moralnych, a zatem z zakresu aksjologii, mogąca być

${ }^{1}$ Ostatnio kwestie te interesująco omówił między innymi Richard Andrews; por. idem, Znaczenie retoryki i argumentacji w szkolnictwie angielskim, przeł. J.Z. Lichański, [w:] Retoryka w edukacji: problemy argumentacji, red. J.Z. Lichański, ,Forum Artis Rhetoricae” 63, 2021, nr 1, s. 9-26.

${ }^{2}$ Prac na ten temat jest sporo, także w internecie; zob. m.in. I. Czaja-Chudyba, Myślenie krytyczne w edukacji, Łódź 2020; T. Kalbarczyk, Nauka krytycznego myślenia, „Analiza i Egzystencja” 25, 2014, s. 7-17.

${ }^{3}$ Por. Protreptyk (gr. Protreptikos = zachęcający), [w:] M. Głowiński, J. Sławiński, T. Kostkiewiczowa, Stownik terminów literackich, Wrocław 1998, s. 441: gatunek dydaktyczny zawierający zachętę do doskonalenia się moralnego i rozwijania zdolności intelektualnych, zwłaszcza zaś wskazówki dotyczące studiowania filozofii: Platon, Arystoteles, Cyceron, Seneka, Laktancjusz; także J.P. Wils, Protreptik, [w:] Historisches Wörterbuch der Rhetorik, t. 7, red. G. Kalivoda, F.H. Robling, T. Zinsmaier, S. Fröhlich, Tübingen 2005, szp. 376-380. 
swoistym przełomem w dydaktyce ${ }^{4}$. Ponieważ nie jest raczej obecnie, poza wydziałami filozofii bądź filologii klasycznej, wykorzystywana w dydaktyce, a już na pewno w dydaktyce szkolnej, kilka słów przypomnienia.

Jak pisze Mason Marshall w studium Reading Plato's Dialogues to Enhance Learning and Inquiry. Exploring Socrates' Use of Protreptic for Student Engagement (Czytanie dialogów Platona w celu usprawnienia uczenia się i dociekań. Odkrywanie sokratejskiego protreptyku w celu wykorzystania go do wyrobienia w uczniach umiejętności samodzielnych badań $)^{5}$ :

Dosłowne znaczenie tego słowa to „Zwrócenie lub skierowanie (kogoś) do/ku określonego(mu) celu(owi) "'; w starożytności protreptyk był, najogólniej mówiąc, tylko wysiłkiem zmierzającym do zmiany zachowania osoby lub aktem zmiany tego zachowania. Ale istniało coś takiego jak filozoficzny protreptyk - nawracanie kogoś lub próba nawrócenia go na filozoficzny sposób życia — i to jest rodzaj protreptyki, która inspiruje moje użycie tego terminu. Użyję terminu ,protreptyczny”, aby odnieść się do próby doprowadzenia kogoś do pewnego rodzaju dochodzenia, co oznacza przede wszystkim próbę doprowadzenia do fundamentalnej przemiany serca, aby bardziej niż czegokolwiek innego pragnęli prawdy. Szukajcie jej w przemyślanej wymianie zdań z innymi ludźmi, którzy są na tyle uczciwi, że podążają wszędzie tam, gdzie prowadzą dowody ${ }^{7}$.

Pozornie uwaga Marshalla odnosi się do kwestii związanych ze studiowaniem dialogów Platona; nic bardziej mylnego! Oto analiza takich dzieł greckiego filozofa, jak Eutyfron, Kriton, Menon, Państwo, pozwala mu na opisanie techniki „działania” protreptyku. Ale właściwie czy jest potrzebna jakaś nowa metoda w edukacji? Jak pisze dalej we wstępie do wspominanej książki Marshall:

[Jest oczywiste, że] demokracja przeżywa kryzys, kiedy obywatele są biednymi myślicielami. Myśl jest również niezbędna nie tylko dla demokratycznych obywateli, ale przede wszystkim dla ludzi, przynajmniej ze względu na jej zdolność do wywoływania zachwytu, podnoszenia umysłu i uwalniania nas od dogmatyzmu i uprzedzeń. Nawet jeśli nie dostarcza wiedzy, może pomóc nam znaleźć drogę do najbardziej rozsądnych i odpowiedzialnych decyzji, jakie możemy podjąć. A świat potrzebuje ludzi, którzy dobrze podejmują decyzje. Potrzebujemy rodziców, małżonków, prawników,

${ }^{4}$ Stosowana między innymi w Kopenhaskiej Szkole Biznesu i Filozofii Przywództwa (Copenhagen Business School of the Philosophy of Leadership); por. https://www.cbs.dk/en/research/departments-and-centres/department-of-management-politics-and-philosophy/center-art-and-leadership/ research (dostęp: 10.06.2021); także O.F. Kirkeby, Protreptik: filosofisk coaching i ledelse, https:// books.google.pl/books?id=FZ3i_ZQ7Ce0C\&pg=PA7\&hl=pl\&source=gbs_toc_r\&cad=3\#v=onepage\&q\&f=false (dostęp: 10.06.2021); idem, Phronesis as the Sense of the Event, „International Journal of Action Research" 5, 2009, nr 1, s. 68-113.

${ }^{5} \mathrm{Na}$ kwestie te zwracał uwagę w Polsce między innymi wspominany Tomasz Kalbarczyk; por. idem, op. cit., s. 10-11: „Kształtowaniu myślenia krytycznego służy bardziej porządek problemowy niż chronologiczny wykładu, podobnie wybór najważniejszych, przełomowych momentów w dziejach filozofii — wraz z ich bardziej szczegółowym omówieniem i próbą oceny — bardziej się przysłuży sprawie niż ambicja przedstawienia pełnego kanonu dokonań filozofów". Por. idem, Wolność a edukacja. Filozofia wychowania we współczesnym liberalizmie, Lublin 2012, zwł. s. 67-71.

${ }^{6} \mathrm{~W}$ oryginale turning or converting (someone) to a specific end, co można rozumieć tak, jak zaproponowałem, bądź: zmienić kierunek lub skierować itd.

${ }^{7}$ M. Marshall, Introduction, [w:] idem, Reading Plato's Dialogues to Enhance Learning and Inquiry. Exploring Socrates'Use of Protreptic for Student Engagement, New York 2021. 
pracowników socjalnych, lekarzy itd., którzy potrafią przeanalizować problem w zdecydowany i poinformowany sposób oraz dostroić się do tego, co dobre i słuszne. Konsekwencją tego jest to, że potrzebujemy prawdziwej debaty na temat głównych kwestii dotyczących tego, jak żyć — debaty, która jest prawdziwa o tyle, o ile jest łaskawa, optymistyczna i produktywna zarówno pomimo szczerości i wigoru, jak i dzięki temu, że jej część ma na celu odnalezienie prawdy nawet za cenę utraty twarzy lub utraty pozycji politycznej. Idea takiej debaty i idea protreptyki są tak samo aktualne jak zawsze, chociaż być może oba są dziedzictwem starożytnej Grecji. Filozofowie i inni, którzy podjęli projekt, który proponuję, studiowaliby Sokratesa, Platona, aby dowiedzieć się czegoś o protreptyce ${ }^{8}$. Pytali, jakie strategie stosuje w rozmowach z innymi ludźmi (na przykład, w jaki sposób może grać na emocjach innych ludzi); oceniliby, które strategie są najlepszymi strategiami, jakie można zastosować w okolicznościach, w których się znajduje; a jeśli istnieją lepsze strategie niż Sokrates, polegaliby na Platonie w analizie tego, czym one są. W trakcie tego procesu po prostu przypuszczaliby pewne rzeczy, na przykład następujące: Sokrates próbuje ulepszyć innych ludzi.

Problem wskazany przez Marshalla może nieco zaskakiwać, bowiem z Sokratesem łączymy tradycyjnie inne metody nauczania. Są to majeutyka oraz metoda elenktyczna9; w ten sposób gubiliśmy ważny trop dydaktyczny, ale i poznawczy. Oto problem - powiada za Sokratesem Marshall — nie tkwi w tym, czy mamy jakąś wcześniejszą wiedzę na jakiś temat, tylko ukrytą i przy pomocy metody majeutycznej „,rodzimy” ją. Daleko istotniejsza jest protreptyka, bowiem ona „prowadzi nas” do celu, jaki sobie postawiliśmy. Pozwala dobrze zrozumieć proces dochodzenia do prawdy. Tu konieczny jest przykład: w dialogu Eutyfron toczy się ważna dyskusja, która dotyczy rozważań na temat sprawiedliwości i pobożności (= zbożności) $)^{10}$ :

SOKRATES: A czy i wszystko, co sprawiedliwe, jest też i zbożne, czy też tylko wszystko, co zbożne, to sprawiedliwe; a sprawiedliwe nie wszystko zbożne, tylko jedno sprawiedliwe będzie zbożne, a drugie jakieś inne?

EUTRYFRON: Nie nadążam, Sokratesie, za słowami.

${ }^{8}$ Por. J.E. Hessler, Socrates Protreptic and Epicurus. Heading trough Philosophy, [w:] Socrates and the Socratic Dialogue, Leiden-Boston 2017, s. 665-681. W naszej tradycji kwestie te omawiał Władysław Witwicki w komentarzu między innymi do dialogu Eutyfron; por. Platon, Eutyfron. Obrona Sokratesa. Kriton, przeł. i oprac. W. Witwicki, Warszawa 1958, s. 53-67. Także https:// wolnelektury.pl/katalog/lektura/platon-eutyfron.html (dostęp: 1.06.2021). Wcześniej na kwestie te zwrócił uwagę między innymi Egidius Schmalzriedt, Platon. Der Schritsteller und die Wahrheit, München 1969, gdzie na s. 81-107 jest przeprowadzona bardzo podobna analiza Eutyfrona.

9 Por. W. Tatarkiewicz, Historia filozofii, t. 1. Filozofia starożytna i średniowieczna, Warszawa 1958, s. 94-97: „metoda elenktyczna”, „metoda maieutyczna”; także S. Blackburn, Oksfordzki słownik filozoficzny, red. J. Woleński, Warszawa 1997, s. 105: elenchus. Metoda elenktyczna polega na badaniu argumentów w dyskusji; metoda majeutyczna — na wydobywaniu w jej toku wiedzy nieuświadomionej przez rozmówców. W obu wypadkach istotnym składnikiem jest ,umiejętne zadawanie pytań".

${ }^{10} \mathrm{~W}$ polskim tłumaczeniu W. Witwickiego jest używany termin ,zbożność”; pozostawiam go, ponieważ w polskiej tradycji jest on używany. W wydaniu polskim por. s. 42-44. Warto zestawić ten fragment z przypowieścią z Ewangelii św. Łukasza, 18.1-8 o niesprawiedliwym sędzim (ibidem, $11 \mathrm{e}-12 \mathrm{~d} 2-2)$. 
SOKRATES: A młodszyś ode mnie z pewnością nie o mniej, niżeś mądrzejszy. Tylko, jak mówię, takeś zmiękł z tego bogactwa mądrości. Ale przecież napij się trochę, mój drogi. Przecież to i nietrudno zrozumieć to, co mówię. Ja mówię po prostu coś przeciwnego, niż wyśpiewał poeta, który powiada ${ }^{11}$ :

Zeusa zaś stwórcy wszechrzeczy, co wszystko spłodził na ziemi,

Nie chcesz wymienić, bo wszędzie, gdzie strach jest, tam i wstyd będzie.

Otóż ja się tym różnię od poety, powiedzieć ci czym?

Eutyfron: Naturalnie.

Sokrates: Mnie się zdaje, że gdzie jest strach, tam wcale nie musi być wstyd. Uważam, że niejeden boi się i choroby, i ubóstwa, i wielu innych takich rzeczy; boi się, ale nie wstydzi się zupełnie tego, czego się boi. Nie wydaje się tak i tobie?

EUTYFRON: Naturalnie.

SOKRaTes: Ale gdzie jest wstyd, tam i strach będzie. Bo czy znajdzie się taki, który by się wstydził jakiegoś czynu i musiał się zań rumienić, a nie bałby się i nie drżałby równocześnie o rozgłos nieprawości?

EUTYFRON: Więc boi się.

SOKRATES: Więc to nie jest prawne powiedzenie: ,gdzie jest strach, tam i wstyd będzie”, ale: gdzie wstyd jest, tam i strach będzie, a nie gdzie strach, tam wszędzie zaraz wstyd. Bo strach, uważam, sięga dalej niż wstyd. Wstyd jest pewną częścią strachu. Podobnie jak liczba nieparzysta jest częścią liczby tak, że nie wszędzie, gdzie tylko liczba, tam i liczba nieparzysta, tylko gdzie jest liczba nieparzysta, tam też jest liczba. No cóż, nadążasz teraz jakoś przecież?

EUTYFRON: Naturalnie.

SOKRATES: Otóż ja i tam w poprzednich słowach pytałem o coś podobnego. Czy gdzie sprawiedliwość, tam i zbożność, czy też gdzie zbożność, tam i sprawiedliwość, ale gdzie sprawiedliwość, tam nie wszędzie zbożność. Bo to, co zbożne, stanowi cząstkę tego, co sprawiedliwe. Tak powiemy, czy inaczej ci się wydaje?

EuTYFRON: Nie; właśnie tak samo. Zdaje mi się, że to poprawnie powiedziane [wyr. — J.Z.L.].

Przyjrzyjmy się bliżej temu fragmentowi (szczególnie miejscom podkreślonym): problem, jaki mają rozwiązać rozmówcy, dotyka kwestii szalenie ważkiej. Chodzi o zależność pomiędzy dwoma terminami sprawiedliwość i pobożność (= zbożność; można oczywiście w trakcie zajęć przyjąć i inne terminy!) ${ }^{12}$. Rozmówcy starają się rozważyć, jaka jest wzajemna relacja pomiędzy nimi, który z nich jest nadrzędny, a który — zależny. Ale także na czym polega owa zależność.

11 Jest to fragment zaginionego eposu Cypria przypisywanego półlegendarnemu poecie Stasinusowi z Cypru, opisującego w 11 księgach wydarzenia poprzedzające wojnę trojańską; por. https:// wolnelektury.pl/katalog/lektura/platon-eutyfron.html (dostęp: 1.06.2021).

12 Można wziąć pod uwagę na przykład dominację i wolność; por. R. McKerrow, Critical Rhetoric: Theory and Praxis, „Communication Monographs” 56, 1989, nr 2, s. 91-111; także D.L. Cloud, Critical Rhetoric. The Critique of Domination and The Critique of Freedom: A Gramscian Perspective - Commentary, „International Journal of Communication” 14, 2020, s. 831-849. 
Jak powiada w swojej analizie Władysław Witwicki (niejako uprzedzając rozważania Marshalla) ${ }^{13}$ :

[c]hcąc rozstrzygnąć teraz, czy jakiś czyn jest zbożny, czy nie, potrzeba sobie naprzód zdać sprawę z tego, czy jest sprawiedliwy; jeśli nie, to nie ma mowy o jego zbożności. [...] Platon ogranicza się tylko do zacieśnienia pojęcia tego, co zbożne, w zakresie sprawiedliwości.

W swej analizie Marshall w sposób dokładniejszy analizuje zależność terminów i pokazuje, w jaki sposób przebiega dyskusja. Kwestie pozornie marginalne, jak na przykład rozważania na temat wstydu, strachu, a następnie arytmetyki, pokazują, jak „układają się” zakresy znaczeniowe określonych terminów. Można je - tak czyni amerykański badacz — przedstawić z wykorzystaniem diagramów Venna ${ }^{14}$, albo też całość postępowania przyrównać do metodyki, która jest zbliżona do opisanej w teorii retoryki. Mam na myśli naukę o status, czyli technikę ustalania zakresu problemu/przedmiotu, który chcemy zbadać, aby go następnie przedstawić w naszym tekście/mowie ${ }^{15}$. Stwierdzamy zatem, że istnieją przedmioty naszego sporu (sprawiedliwość i pobożność (= zbożność)); następnie analizujemy kwestie, takie jak: czym są oraz jakie są sprawiedliwość i pobożność. Aby to wyjaśnić, Platon wprowadza następujące rozważania: a jak przedstawiają się te kwestie, gdy przeanalizujemy zakresy (znaczeniowe) takich terminów, jak wstyd, strach czy też liczba i liczba nieparzysta. W ten sposób filozof pokazuje, że jakiś termin, na przykład sprawiedliwość, jest ogólniejszy niż pojęcie pobożności.

Można zatem postawić tezę, że protreptyk stosuje metodę łączącą naukę o status z postępowaniem stosowanym przy konstrukcji i analizie sylogizmów z jednoczesnym uzasadnianiem kolejnych przesłanek (epicheiremat). W cytowanym przykładzie Sokrates sięga po takie terminy, jak strach, wstyd, przykład $\mathrm{z}$ arytmetyki, i służą one tylko do uzasadniania poprawności ograniczania zakresów znaczeniowych, jakie zachodzą pomiędzy głównymi terminami — sprawiedliwość i pobożność (= zbożność).

Powiedzmy zatem, że — do pewnego stopnia — rozumowania, jakie prezentują Sokrates i Eutyfron, są odmianą rozumowań per analogiam. Nie sądzę, aby było to w pełni trafne spostrzeżenie; chodzi bowiem o kwestię, który z terminów ma szerszy zakres, a nie o jakieś podobieństwo pomiędzy przywołanymi pojęciami. Okazuje się, że sprawiedliwość ma zakres najszerszy; pojęcie pobożności (= zbożności) jest jej podporządkowane.

${ }^{13}$ Por. W. Witwicki, Objaśnienia tłumacza, [w:] Platon, op. cit., s. 61-62; M. Marshall, op. cit. (rozdz. 2).

14 Diagramy Venna to schemat, który służy ilustrowaniu zależności między zbiorami lub zakresami terminów; por. Logika formalna. Zarys encyklopedyczny z zastosowaniem do informatyki i lingwistyki, red. W. Marciszewski, Warszawa 1987, s. 34.

15 Por. J. Martin, Antike Rhetorik. Technik und Methode, München 1974, s. $28-52$. 
Opisana metoda wygląda na skomplikowaną; tymczasem opiera się na przestrzeganiu poprawności rozumienia zakresów znaczeniowych terminów ${ }^{16}$. W praktyce zapewne trzeba byłoby sięgnąć do słowników, podać więcej przykładów itd. Niemniej jednak metoda tu przedstawiona ma jeszcze jedną zaletę: angażuje uczestników dialogu do wysiłku myślenia i analizowania znaczeń pojęć, których się używa, czyli - wprowadza element myślenia krytycznego.

Przy niezbyt uważnej lekturze książki Marshalla może pojawić się pytanie, dlaczego tak wiele w niej odwołań do kwestii dydaktycznych. Otóż jest tak, ponieważ dzisiejsza dydaktyka przypomina wciąż bardzo dawną metodę uczenia: lektura i analiza wzoru, z reguły tekstu literackiego, według którego piszemy następnie nowe opracowanie. Metoda ta zostaje poddana krytyce nie tylko w pracy Marshalla, ale między innymi w studium Richarda Andrewsa, który pisze wręcz ${ }^{17}$ :

Progymnasmata to ćwiczenia podręcznikowe oparte na prostym modelu pedagogicznym: zasada, przykład, naśladownictwo. Mówiąc dokładniej: podejście to polegało na nakreśleniu zasady „działania” retorycznego, następnie podawano przykład, a uczeń miał naśladować ten przykład. Taka sztywna, formalna pedagogika ograniczona była do przekazywania wzorów i musiała stać się nużąca jako praktyka dla studentów (i uczniów); ale także unicestwiała dynamiczną, dopasowaną do celu naturę samej retoryki w jej redukcji z żywej praktyki społecznej do zbioru zasad i przepisów.

Zaproponowane przez Marshalla podejście radykalnie odrzuca ten wzór na rzecz właśnie pełnego zaangażowania i uczącego, i uczonego w proces odkrywania, dochodzenia do poznania przedmiotu wspólnego badania. Jak sądzę, położenie nacisku na wspólnotę badania jest niezwykle ważną zmianą metodyczną, jaką proponuje Marshall.

Książka Marshalla, i przypomniana w niej metoda dydaktyczna, jest zatem niezwykle ważnym głosem $\mathrm{w}$ obecnej dyskusji na temat konieczności dokonania zmian $\mathrm{w}$ dość skostniałej technice dydaktycznej ${ }^{18}$. Właśnie protreptyka może stać się tym nowym narzędziem, które pozwoli na rozwój intelektualny uczniów, a sam proces dydaktyczny uczyni daleko bardziej atrakcyjnym ${ }^{19}$. Jak powiada Ole Fogh Kirkeby ${ }^{20}$ :

Określając epistemologiczne ramy komunikacji, z silnym naciskiem na dialog, sens wydarzenia musi być warunkiem sine qua non badań nad działaniem [można to odnieść szerzej, także do... lekcji - J.Z.L]. W tym kontekście fronesis oznaczałaby zdolność do przyjmowania i tworzenia w odniesieniu do istoty [określającej odrębność] drugiej osoby. W badaniach nad działaniem doktryna fronesis, która przyjmuje, że każda osoba jest unikalną istotą, musi zarówno kierować, jak i uzasadniać ten typ badań [wyr. - J.Z.L].

$16 \mathrm{Na}$,poprawność rozumienia” muszą zgodzić się wszyscy uczestnicy dyskusji/debaty; inaczej cała rozmowa traci sens.

${ }^{17}$ R. Andrews, op. cit., s. 11.

18 Sądzę, że książka ta powinna być koniecznie przetłumaczona na język polski.

19 Świadczyć o tym może między innymi podręcznik służący do nauczania coachingu; por.

O.F. Kirkeby, Protreptik... - jest przekład angielski tej książki.

${ }^{20}$ O.F. Kirkeby, Phronesis..., s. 70. 
Tym bardziej można przyjąć, że właśnie protreptyk, który opiera się na dialogu, jest prawie idealnym narzędziem dydaktycznym. Co więcej, niejako ,przy okazji” zastosowanie go ułatwi coś, co sprawia w dydaktyce sporo kłopotu, a mianowicie - proces uczenia krytycznego myślenia, i lepiej przygotuje uczniów, a także studentów do życia w społeczeństwie demokratycznym ${ }^{21}$.

\section{Bibliografia}

Andrews R., Znaczenie retoryki i argumentacji w szkolnictwie angielskim, przeł. J.Z. Lichański, [w:] Retoryka w edukacji: problemy argumentacji, red. J.Z. Lichański, „Forum Artis Rhetoricae" 63, 2021, nr 1 .

Blackburn S., Oksfordzki słownik filozoficzny, red. J. Woleński, Warszawa 1997.

Bruner J.S., O poznawaniu. Szkice na lewa rękę, przeł. Z. Fonferko, Warszawa 1971.

Callard A., Everyone Desires the Good. Socrates' Protreptic Theory of Desire, „Review of Metphysics" 70, 2017, nr 4.

Cloud D.L., Critical Rhetoric. The Critique of Domination and The Critique of Freedom: A Gramscian Perspective - Commentary, „International Journal of Communication” 14, 2020.

Czaja-Chudyba I., Myślenie krytyczne w edukacji, Łódź 2020.

Głowiński M., Sławiński J., Kostkiewiczowa T., Słownik terminów literackich, Wrocław 1998.

Hessler J.E., Socrates Protreptic and Epicurus. Heading trough Philosophy, [w:] Socrates and the Socratic Dialogue, Leiden-Boston 2017.

Kalbarczyk T., Wolność a edukacja. Filozofia wychowania we wspótczesnym liberalizmie, Lublin 2012.

Kalbarczyk T., Nauka krytycznego myślenia, „Analiza i Egzystencja” 25, 2014.

Kirkeby O.F., Protreptik: filosofisk co aching $i$ ledelse, https://books.google.pl/books?id=FZ3i ZQ7Ce0C\&pg=PA7\&hl=pl\&source=gbs_toc_r\&cad=3\#v=onepage\&q\&f=false.

Kirkeby O.F., Phronesis as the Sense of the Event, „International Journal of Action Research” 5, 2009, nr 1.

Logika formalna, [w:] Logika formalna. Zarys encyklopedyczny z zastosowaniem do informatyki i lingwistyki, red. W. Marciszewski, Warszawa 1987.

Marshall M., Reading Plato's Dialogues to Enhance Learning and Inquiry. Exploring Socrates'Use of Protreptic for Student Engagement, New York 2021, ,Routledge International Studies in the Philosophy of Education".

Martin J., Antike Rhetorik. Technik und Methode, Mnchen 1974.

McKerrow R., Critical Rhetoric: Theory and Praxis, „Communication Monographs” 56, 1989, nr 2.

Platon, Eutyfron. Obrona Sokratesa. Kriton, przeł., oprac. W. Witwicki, Warszawa 1958.

Schmalzriedt E., Platon. Der Schriftsteller und die Wahrheit, München 1969.

Tatarkiewicz W., Historia filozofii, t. 1-3, Warszawa 1958.

Wils J.P., Protreptik, [w:] Historisches Wörterbuch der Rhetorik, t. 7, red. G. Kalivoda, F.H. Robling, T. Zinsmaier, S. Fröhlich, Tübingen 2005.

${ }^{21}$ O kwestii tej wspominał już J. Dewey (,Wiedza zdobyta samodzielnie jest szczególnie cenna — jest »prawdziwą własnością dziecka«"), a przypomniał między innymi J.S. Bruner w swym opracowaniu O poznawaniu. Szkice na lewa rękę, przeł. Z. Fonferko, Warszawa 1971, s. 161; por. T. Kalbarczyk, Nauka..., s. 12. 